\title{
Obez ve Obeziteden Kurtulmuş Bireylerin Obeziteye Yönelik Tutumları ve Yaşam Kalitelerinin Karşılaştırılması: Niteliksel Çalışma
}

\author{
Sevcan Karataş ${ }^{1}$, Nurcan Hamzaoğlu²]
}

IIstanbul Yeni Yüzyıl Üniversitesi, Sağlık Hizmetleri Meslek Yüksek Okulu, İstanbul, Türkiye

2istanbul Yeni Yüzyıl Üniversitesi, Sağlık Bilimleri Enstitüsü, İstanbul, Türkiye

Sevcan Karataş, Öğr. Gör. Nurcan Hamzaoğlu, Dr. Öğr. Üyesi

Iletişim:

Öğr. Gör. Sevcan Karataş

İstanbul Yeni Yüzyll Üniversitesi,

Sağlık Hizmetleri Meslek Yüksek Okulu,

İstanbul, Türkiye

Tel: +905435858789

E-Posta: sevcan.karatas@yeniyuzyil.edu.tr

\section{ÖZET}

Amaç: Obezite tanısı almış kişilerin yaşam kaliteleri ve obeziteye karşı tutumları ile obezite tanısı alarak çeşitli yollarla obeziteden kurtulmuş bireylerin yaşam kalitelerinin karşılaştırılması amacıyla gerçekleştirilmiştir.

Yöntem: Çalışmanın evrenini İstanbul'da yaşayan, obezite tanısı almış ve çeşitli yollarla obeziteden kurtulmuş bireyler oluşturmaktadır. Örneklemini ise, obezite tanısı almış 15 birey ve obeziteden kurtulmuş 15 birey oluşturmuştur. Çalışma verileri derinlemesine görüşme tekniği kullanılarak elde edilmiştir. Veriler in toplanmasında tarafımızdan oluşturulan 11 sorunun bulunduğu demografik veri elde etme formu ve 3'er açık uçlu sorunun bulunduğu veri toplama formları kullanılımıştı. Elde edilen veriler tümevarımc içerik analizi yöntemi ile değerlendirilmiştir.

Bulgular: Yapılan derinlemesine görüşmeler sonucunda 15 obez katılımanın \%80'i obezitenin hayatlarını yalnızca psikososyal boyutta etkilediğini belirtmiştir. Obeziteden kurtulmak iç̧in herhangi bir girişimde bulunup bulunulmadığı sorulduğunda ise; \%60'ının kilo vermek için çaba sarf ettiklerini, fakat \% $40^{\prime}$ ının ise rahatsızlıklarııı yok sayarak hayatla barışık olduklarını ifade ettikleri görülmüştür. Obeziteye sebep olan faktörler sorulduğunda ise; \%67'si aşırı yemek yeme, hareketsiz yaşam gibi bireysel faktörlerden kaynaklandığını, \%33'ü ise çeşitli ilaç kullanma ve fiziksel çevre koşulları gibi ikincil faktörlerden kaynaklandığını ifade etmiştir. Obeziteden kurtulmuş katılımcıların tamamının $(\mathrm{N}=15)$ psikososyal faktörlerden etkilenerek bu kararı aldığı görülmüştür. Ancak obeziteden kurtulduklarında hayatlarındaki değişiklikler sorulduğunda ise özgüvenlerinin artmasının yanı sıra fizyolojik yaşam kalitelerinin de arttı̆ı̆ıı belirtmişlerdir.

Sonuç: Çalışmanın sonucunda, obez katılımcıların hayatının psikososyal ve fizyolojik anlamda olumsuz etkilendiği görülmüştür. Katılımcıların obeziteden kurtulmak için girişimde bulunmalarında yalıızca psikososyal etmenlerin etkili olduğu fakat obeziteden kurtulduktan sonra fizyolojik olarak da rahatladıklarını ve sağıklarını kaybetmek üzere olduklarını ancak obeziteden kurtulduktan sonra fark ettikleri sonucuna ulaşılmıştır.

Anahtar sözcükler: Obezite, sağlıkı yaşam, yaşam kalitesi, obeziteden kurtulmak

\section{A COMPARISON OF LIFE QUALITY AND ATTITUDE TOWARDS OBESITY BETWEEN PEOPLE WHO GET A DIAGNOSIS OF OBESITY} AND GET RID OF OBESITY: QUALITATIVE STUDY

\section{ABSTRACT}

Objectives: The purpose of this study is to compare life quality and attitude towards obesity between people who get a diagnosis of obesity and get rid of obesity.

Methods: The sampling universe for this study consisted of people who live in Istanbul, get a diagnosis of obesity and get rid of obesity. The subject of the study has been assigned to the purposive sampling method, 15 people who got diagnosed with obesity and 15 people that got rid of obesity. In-depth interview techniques were carried out to collect data. Two different information forms were applied to two groups. The demographical information form that has the same 11 questions was created by us and implemented for the groups. In addition, the two different forms that include different three open-ended questions were implemented for two groups. The inductive analysis technique used to analyse the data obtained.

Results: As a result of the in-depth interviews, when asked to the 15 participants how obesity affects their life, $80 \%$ of them mentioned only psychosocial effects. When asked about the factors that cause obesity; $67 \%$ said that it originates from personal factors such as excessive eating and sedentary lifestyle, but $33 \%$ said that it originates from secondary factors like the usage of various medicines and physical environmental conditions. All participants $(\mathrm{N}=15)$ pointed out to have been affected by the psychosocial factors to get rid of obesity. But, when asked what changes in their lives after getting rid of obesity; they defined to increase in self-esteem for decreasing psychosocial pressures and increase physiological quality.

Conclusion: As a result, the life of obese participants is adversely affected by psychosocial and physiological aspects. The participants have indicated personal and secondary factors that caused them to be overweight. It is impressive for participants to attempt to get rid of obesity for only psychosocial factors, but they defined that they felt relieved psychologically and realised that they are about to lose their health after getting rid of obesity.

Keywords: obesity, healthy lifestyle, life quality, get rid of obesity
Revizyon Tarihi : 13 Mayıs 2019

Kabul Tarihi : : 08 Ekim 2019 
$\mathrm{H}$ alk arasında aşırı şişmanlık olarak bilinen obezite, Dünya Sağlık Örgütü (DSÖ) tarafından; 'vücut yağ miktarının sağlığı bozacak şekilde aşırı veya anormal birikmesi' olarak tanımlanmaktadır (1). Obezite için; kişinin ağırlığının, boy, cinsiyet ve genetik özellikleri baz alınarak belirlenen ideal değerlerin üzerinde olması besinlerle birlikte alınan enerjinin, harcanan enerjiden fazla olması ve fazla olan enerjinin vücutta yağ olarak birikmesi (2) gibi tanımlar yapmak da yanlış değildir. Obeziteyi, basit obezite ve sekonder obezite olmak üzere iki farklı başlık altında değerlendirmek mümkündür (3). Yalnızca kalori alımının yakılan kaloriden fazla olması ve obeziteye sebep olabilecek bir hastalığın bulunmaması durumu basit obezite; genetik ve hormonal faktörlerin de etkili olduğu ve obeziteye sebep olabilecek hastalıkların da bulunduğu durum ise sekonder obezite olarak adlandırılmaktadır (4). Obezitenin toplumun her kesiminde görülen yaygın bir problem olması nedeniyle tanı yöntemi olarak ucuz kolay ve doğruluk oranı yüksek olan beden kitle indeksi BKi kullanılmaktadır (5). BKí, vücut ağılığının (kg) boy uzunluğunun $(m)$ karesine bölünmesi ile elde edilen sayısal bir değerdir. BKi değeri, 25,00 ile 29,99 arasında olan bireylerin, şişmanlık öncesi evrede (pre-obez) olduğu, BKi $\geq 30,0$ olan bireylerin ise obez olduğu kabul edilmektedir (1).

Birçok kronik hastalık obeziteye sebep olabileceği gibi, obezite de birçok hastalığa sebep olabilmektedir. Tanımlardan da anlaşılacağı gibi obezite, kişilerin yaşam kalitesini olumsuz etkileyen multifaktöriyel bir hastalıktır. Kişilerin yaşam kalitesini ve süresini etkilemesinin yanı sıra, tip II diyabet, hipertansiyon, aterosikleroz, tromboembolizm, astım, apne ve birçok kanser türünün de habercisi olduğu bilinmektedir (3). Obezitenin kişiye verdiği fizyolojik ve fiziksel zararların yanı sıra psikososyal boyutta kronik ve ilerleyici bir hastalık olduğunu da belirtmek gerekmektedir (6). Obez hastalar $(n=53)$ ile yapılan bir çalışmada, hastaların \% 81,3'ünde ( $n=43$ ) majör depresif bozukluk, \% 22,6'sında ( $n=12$ ) sosyal fobi, \% 5,7'sinde ( $n=3$ ) yaygın anksiyete bozukluğu tespit edilmiştir (7).

Günümüzde, çocukluk ve ergenlik döneminde sıkça karşılaşılan kronik hastalıklardan birisi olan obezite gelişmiş ve özellikle sanayileşmenin gelişmekte olduğu ülkelerde en önemli sağlık sorunları arasında yer almaktadır ve Dünya Sağlık Örgütü tarafından en riskli on hastalık arasında gösterilmektedir (8). DSÖ nün 2006 verilerine göre dünyada 400 milyon olarak bildirilen obezite sayısının, 2015 yılındaki verilerde 700 milyona ulaştığı görülmektedir (9). Türkiye İstatistik Kurumu (TÜiK) 2014 verilerine göre ise Türkiye'deki 15 yaş ve üzeri bireylerde obezite görülme oranı \% 19,9, 2016 yılında ise \% 19,6'dır (10). 2016 yılında elde edilen bu verilere göre Türkiye Avrupa'daki en çok obezite görülen ülkeler arasında 4. sırada yer almaktadır. Listenin ilk sırasında \% 25,2 ile Malta, en son sırasında ise $\% 12,9^{\prime}$ luk oran ile Hollanda yer almaktadır (10).

Yirmi yıldan daha uzun bir süredir obezite küresel bir salgın haline gelmiştir. Obezitenin tedavisinde; tıbbi beslenme (diyet) tedavisi, egzersiz tedavisi, farmakolojik tedavi, davranış değişikliği tedavisi ve cerrahi tedavi gibi yöntemler kullanılmaktadır. Fakat bütün hastalıklarda olduğu gibi obezitede de önlenebilir koruyucu sağlık uygulamalarının öncelik kazanması son derece önemlidir. Aksi takdirde obezite prevalansının artması ile obezite ve beraberinde gelen hastalıkların tedavisi için yapılan sağlık harcamaları da aynı oranda artış gösterecektir (5). Amerika'da BKi $\geq 30$ olan bireylerle yapılan bir çalışmada, bu bireylerin yıllık sağlık harcamalarının normal BKi bireylere oranla \% 36 daha fazla olduğu tespit edilmiştir (11). Yine aynı çalışmada, obez kişilerin altta yatan kronik hastalıkları nedeniyle işe devamlarının azaldığı ve iş gücündeki kayıplar ile üretkenliğin de azaldığı sonucuna varılmıştır (11).

Bu çalışmada obezite tanısı almış kişilerin yaşam kaliteleri ve obeziteye karşı tutumları ile obezite tanısı aldıktan sonra obeziteden kurtulmuş bireylerin yaşam kalitelerinin karşılaştırılması ve her iki grubun obeziteye yönelik algılarının yaşam kalitesi üzerindeki etkilerine yönelik farkındalık düzeylerinin belirlenmesi amaçlanmıştır.

\section{Yöntem}

Obezite tanısı almış ve obeziteden kurtulmuş bireylerin yaşam kalitelerinin karşılaştııımasını amaçladığımız bu çalışmada fenomenolojik araştırma yöntemi kullanılmıştır. Nitel bir araştırma yöntemi olan fenomenolojik çalışmalarda temel veri katılımcı ile araştırmacı arasındaki derin görüşme ile elde edilir ve genellikle az sayıda katılımcı ile yürütülür (12).

Çalışmanın evrenini İstanbul'da yaşayan, obezite tanısı almış ve çeşitli yollar ile obeziteden kurtulmuş bireyler oluşturmuştur. Örneklemini ise, amaçlı örnekleme yöntemi ile seçilmiş, obezite tanısı almış 15 birey ve obeziteden kurtulmuş 15 birey oluşturmuştur. Çalışma yaklaşık olarak beş ay sonunda tamamlanmıştır. Her iki grup için de tarafımızdan oluşturulan ve aynı 11 sorunun bulunduğu demografik veri elde etme formu ve her iki grup için farklı oluşturulmuş;

Obeziteden kurtulmuş bireyler için;

- Obeziteden kurtulmaya ne zaman karar verdiğinizi anımsayabilir misiniz? 
- Bu süreçte zorluk yaşadınız mı? Ne hissettiniz?

- Sağlıklı vücut ağırlığına ulaştıktan sonra hayatınızda değişiklik oldu mu?

Hala obez olan bireyler için ise;

- Obezite hayatınızı nasıl etkiliyor?

- Obeziteden kurtulmak için çaba harcadınız mı ya da harcadığınızı düşünüyor musunuz?

- Sizce kilo almanızın sebebi neydi?

şeklinde üçer açık uçlu sorunun da bulunduğu veri toplama formları kullanılmıştır.

Çalışma için İstanbul Yeni Yüzyıl Üniversitesi Etik kurulunun 03.12.2018 tarih ve 2018/10 sayılı onayı alındıktan sonra amaçlı örnekleme yöntemi ile katılımcılar seçilmiştir. Araştırmaya toplam $(n=30)$ birey katılmıştır. Araştırma verileri, 15.12.2018 ile 30.01.2018 tarihleri arasında toplanmıştır. Çalışma verileri derinlemesine görüşme tekniği kullanılarak elde edilmiştir. Verilerin kaydedilmesinde ses kayıt cihazı kullanılmış ve bunun için katılımcılardan yazılı ve sözlü onam alınmıştır. Elde edilen verilerin analizinde ise verileri açıklayabilecek kavram ve kavramlar arası ilişkilere kolay ulaşılabilmesi adına tümevarımcı içerik analizi yöntemi kullanılmıştır.

\section{Bulgular}

\section{Katılımcıların tanıtıcı özellikleri}

\section{Tablo 1. Kişisel özelliklerin dağılımı}

\begin{tabular}{lccc} 
& & $\boldsymbol{n}$ & $\%$ \\
\hline Cinsiyet & Kadın & 14 & 47 \\
\hline Yaş & Erkek & 16 & 53 \\
\hline Meslek & $19-28$ & 22 & 73 \\
& $29-45$ & 8 & 27 \\
\hline Eğitim Durumu & Öğrenci & 12 & 40 \\
& Serbest Çalışan & 18 & 60 \\
\hline Lisans ve & 10 & 33 \\
\hline Medeni Durum & Lisansüstü & 8 & 27 \\
& Lise & 12 & 40 \\
\hline Kronik Hastalık & Ortaokul & 12 & 40 \\
& Evli & 18 & 60 \\
\hline Zayıflamak İçin Profesyonel & Bekâr & 9 & 30 \\
Destek Alma* & Var & 21 & 70 \\
\hline \multirow{2}{*}{ Evet } & 5 & 33 \\
& Yok & 10 & 67 \\
\hline
\end{tabular}

*Yalnızca obeziteden kurtulmuş bireyler için
Katılımcıların obeziteye yönelik düşünceleri

Tablo 2. Obez bireylerin obeziteye yönelik düşünceleri

\begin{tabular}{lcc} 
Kategoriler & Temalar \\
\hline 1. & Obezitenin kişilerin hayatını nasıl etkilediği & Psikolojik \\
& & Fiziksel \\
\hline 2. & Obezitenin olumsuz etkilerinden kurtulma yolları & Kilo verme çabası \\
& & Yok sayma \\
\hline 3. Hızlı kilo alma nedenlerini yorumlama şekli & Kişisel faktörler \\
& İkincil faktörler
\end{tabular}

Tablo 3. Obeziteden kurtulmuş bireylerin obeziteye yönelik düşünceleri

\begin{tabular}{llc} 
Kategoriler & Temalar \\
\hline $\begin{array}{l}\text { 1. } \\
\text { Obeziteden kurtulmaya karar vermede } \\
\text { etkili olan nedenler }\end{array}$ & Psikososyal etkiler \\
\hline 2. & $\begin{array}{l}\text { Obeziteden kurtulduktan sonra } \\
\text { oluşan değişiklikler }\end{array}$ & $\begin{array}{l}\text { Özgüvenin artması } \\
\text { Fizyolojik yaşam } \\
\text { kalitesinin artması }\end{array}$ \\
&
\end{tabular}

\section{Obez bireylerin obeziteye yönelik düşünceleri}

\section{Obezitenin kişilerin hayatını nasıl etkilediği}

Obez bireylere obezitenin hayatlarını nasıl etkilediği sorulduğunda, bir grup katılımcının ( $n=12$ ) yalnızca psikolojik sebeplerden yakındığı görülmüştür (Tablo 2).

\section{Psikolojik}

Katılımcılardan bazıları, "...sorunlar var.. Çünkü insanların giyindiği gibi giyinemiyorsun bir noktada. İşte onlar gibi güzel tişörtler giyemiyorsun. Bu konuda biraz sorunlar olabiliyor." (Katılımcı 6, BKi:37,6) ya da "....arkadaş ortamında bu tarz dalga konusu oluyor. Küçüklükten de zaten bu tarz dalgalara maruz kalıyorduk. Yani şişko çocuk, şişman çocuk gibi terimler... IIIII yani bazı ortamlarda insanlar sıkılıyor. Mesela otobüse binerken bir insan sizin yanınıza oturmak istemiyor. Tabi ailede de bazen bunlara maruz kalıyoruz. Iş̧te az yemek ye.. kilo ver.. fazla şişmanladın falan..." (Katılımcı 2, $B K i: 46,74)$ şeklindeki ifadelerle obezitenin hayatlarını daha çok psikolojik anlamda etkilediğinden söz etmişlerdir. Yapılan çalışmalar obez bireylerin anksiyete ve depresyon düzeylerinin obez olmayan bireylere göre daha yüksek olduğunu, benlik saygılarının ise obez olmayan bireylerden daha düşük olduğunu göstermiştir (12-15). Katılımcıların ifadelerinden ve yapılan bu çalışmalardan da anlaşılacağı üzere obezite, kişilerin hayatını psikolojik anlamda olumsuz etkilemekte ve özgüven eksikliği, beden algısında bozulmalara sebep olmaktadır. 


\section{Fiziksel}

Bir kısım katılımcı ise $(n=3)$ obezitenin yalnızca bedenlerine yansıyan fiziksel zorluklarından söz etmiş ve şu ifadeleri kullanmışlardır: "Valla her yönden etkiliyor. Sağlığımı etkiliyor. Her şey kısıtlıyor beni. Ayaklarımda rahatsızlık var, kilodan dolayı. Biraz kilo versem yürüyeceğim. Yürüyemiyorum..." (Katılımcı 1, BKi:53,44), "Zor etkiliyor. Yani şu şekilde: Eeee uzun süre ayakta kalamıyorum. Çok yoruluyorum. Fazla yürüyemiyorum. Merdiven çıkamıyorum. Sürekli asansör kullanmak zorunda kalıyorum."(Katılımcı 3, BKi:44,85). Obezitenin, kişilerin fiziksel açıdan kısıtlanmasında etkisinin büyük olduğu bilinmektedir. Obezite, dejeneratif eklem hastalığı olarak bilinen osteoartritin gelişiminde majör risk faktörleri arasında gösterilmektedir (6). Amerika' da yapılan bir çalışmanın (1997) verileri, kişilerin BKi'lerinin 36 yıl sonraki osteoartrit gelişimini tahmin edebileceğini ortaya koymaktadır (13). Yapılan bir başka çalışmada (2014) ise, BKI'nin her 1 birim artışının osteoartrite bağlı diz ağrıların da 1,18 kat arışına sebep olduğu bulgusu elde edilmiştir (16). Bizim çalışmamızdan elde edilen bulgularda da, katılımcılar hareket etmekte ve yürümekte zorlandıklarından söz etmiştir. Yapılan bu çalışmalardan da anlaşılacağı gibi, obezitenin özellikle alt ekstremite fonksiyonları ile ilgili problemlerde rolünün büyük olduğu açık bir şekilde görülmektedir.

\section{Obezitenin olumsuz etkilerinden kurtulma yolları}

Obezitenin fiziksel ve psikolojik zorluklarından söz eden katılımcılara, bu zorluklardan kurtulmak dolayısı ile obeziteden kurtulmak için herhangi bir girişimde bulunup bulunmadıkları sorulduğunda; katılımcıların bir kısmının kilo vermek için bazı girişimlerde bulunduğu, bir kısmının ise rahatsızlıklarına rağmen mevcut sıkıntılarını göz ardı ettiği-görülmüştür.

\section{Kilo verme çabası}

Katılımcılardan bazıları kilo vermek ve obeziteden kurtulmak için harcadıkları çabaları şu sözlerle ifade ettiler: "Yani daha önceleri diyetisyene gittiğim oldu. Ama bunu çok uzun süre devam ettirmedim. Sonra spora başlama kararı aldım. Sonra spora da gitmedim yani. Bu şekilde..." (Katılımcı 13, BKi: 43,75), "Üniversite döneminde.. 5 yıl önce zayıflamaya karar verdim. Spor salonuna da yazıldım. Yani bir 10-15 gün iyi devam etti. Güzel geçti. Tabi diyetisyene falan gitmedim. Hep kendi çabalarımla. Fiziksel anlamda baya bi yorgunluk hissettim. Yapamayacağımı anladım daha doğrusu psikolojik olarak. Bir daha da 2012 den buyana, 6 yıl geçti işte üstünden, böyle bir çabaya girişmedim." (Katılımcı 12, BKi:43,74). Obezite tedavisine bütüncül olarak yaklaşmak, iyi bir sonuca ulaşabilmek için son derece önemlidir. Kişilere uygun diyet programları, egzersiz programları, farmakolojik tedavi yöntemleri, davranış değişikliği terapileri ve gerekli ise cerrahi müdahaleler birbirine paralel bir şekilde ilerlediğinde başarılı sonuç alınacağını söylemek mümkündür (9). Aksi takdirde, mevcut çalışmada da olduğu gibi yapılan yanlış uygulamalarla birlikte kişilerde başarısızlık hissi ve mental yorgunluk oluşarak, kilo vermek için atılan adımlar sonuçsuz kalacaktır.

Yok sayma

Katılımcıların tamamı obeziteden fiziksel ya da psikolojik anlamda olumsuz etkilendiklerini dile getirmelerine rağmen bazı katılımcıların obezitenin olumsuz etkilerini yok sayma, görmezden gelme eğiliminde olduklarını, "Valla ben kendimi bu şekilde kabul etmişim, bu şekilde görmüşüm, bu şekilde sevmişim. Onun için hani onu düzeltme çabasında falan bulunmuyorum..." (Katılımcı 5, BKi: 43,75) gibi cümlelerle ifade etmişlerdir. Obezite ile mücadele edebilmek için kişilerin gerçek kilosunun hangi boyutta olduğunu algılayabilmesi son derece önemlidir. Obez bireyler gerçek kiloları hakkında bir problem olduğunu düşünmezse, gerekli tedbirleri alamayacak ya da bu durumdan kurtulmak için gerekli adımları da atamayacaklardır. Obez bireyler ile yapılan bir çalışmada (2014) katılımcıların \%61'inin kendilerini normal kiloda gördükleri saptanmıştır (17). Uzun süre- obez olan bireylerin kilolarını benimsemeleri nedeni ile kendilerini normal kilodaymış gibi algılamaya başladıklarını söylemek mümkündür. Algıda bozukluk nedeni ile ortaya çıkan bu durum kişilerin obeziteden kurtulmasını önleyen en büyük engellerden biridir.. Gerçek beden yapısı ile kiş̧ilerin kendi beden algılarının örtüşmesi obezite ile mücadelenin önemli bir paçasını oluşturmakta ve kilo verme stratejilerinin belirlenmesinde önemli rol üstlenmektedir. Obez bireylerin obeziteden kurtulabilmesi için ilk adım kişilerin doğru beden algısını kabullenmeleri ile mümkün olacaktır.

\section{Kilo alma nedenlerini yorumlama şekilleri}

Obez bireylere kilo alma nedenlerini nasıl yorumladıkları sorulduğunda, katılımcıların bir kısmının kilo alma nedenlerine sebep olarak kişisel faktörleri gösterdikleri, bir kısmın ise ikincil faktörleri gösterdikleri tespit edilmiştir.

\section{Kişisel faktörler}

Obez bireylerden bazıları kilo almalarına sebep olarak yanlış beslenme şekilleri ve hareketsizlik gibi kişisel faktörleri işaret ederek, "Hmmm.. Şöyle.. Hareketsizlik, beslenme bozukluğu diyebilirim. Çünkü eğitim hayatım boyunca sürekli ders çalış, bilgisayar oyunu oyna, düzensiz beslen..." (Katılımcı 6, BKI: 37,60) ve "Ya benim hızlı kilo almam hızlı yemem. Çok hızlı yiyen biriyimdir. Yani nefes almadan yemek yerim. Bu tabi beni etkiliyor. Düzensiz beslenme var bende. Hamur işlerine fazla yoğunluk gösteriyorum. Mesela ekmek. Çok seviyorum 
ekmeği. Ne bileyim işte.. Baklava mesela. Bu sefer dengesiz bir kilo alımı oluyor." (Katıımcı 2, BKi: 46,74) ifadelerini kullanmışlardır. Esas olarak enerji alınması ve harcanması arasındaki dengesizlik nedeniyle ortaya çıkan obezitenin oluşmasında birçok faktörün etkili olduğu bilinmektedir. Aktivite yetersizliği, yanlış beslenme düzeni gibi kişinin bireysel olarak yönlendirebileceği faktörler de obezitenin oluşmasında büyük bir yer kaplamaktadır. Özellikle ilerleyen yaşlarda yavaşlayan bazal metabolizma hızına ek olarak, kişinin enerji alımını kısıtlamaması ve yeterli miktarda enerji harcamaması durumunda, özellikle kadınlarda obeziteden kaçınmak mümkün değildir (9). Şehirleşmenin getirdiği ulaşılabilirlik ile birlikte hareketsiz bir yaşam tarzı ve fast-food tüketiminin artması ile obezite arasında doğru bir orantı olduğu düşünülmektedir (9). Beslenme, kişilerin hayatında bebeklik döneminde, anne sütü ile başlayarak ilerleyen yaşlarda alışkanlık olarak devam eden bir süreçtir. Beslenme alışkanlığının, aileler tarafından çocuklara küçük yaşlarda doğru şekilde kazandırılmasının ilerleyen yaşlarda obezitenin ortaya çıkmasının da önüne geçilmesinde büyük bir etkisi olacağını söylemek mümkündür.

\section{İkincil faktörler}

Katılımcılardan bazıları ise kilo almalarına sebep olarak kendi bireysel tercihleri dışında gelişen ikincil faktörleri neden olarak göstermiştir. Obezitenin ortaya çıkmasında yanlış beslenme, hareketsiz bir yaşam gibi kişisel faktörler etkili olabileceği gibi, kişinin genetik ve hormonal yapısının, sosyo-ekonomik düzeyinin, çeşitli psikolojik ve çevresel faktörlerin de etkili olduğu bilinmektedir (9). Obez katılımcılardan birisi kilo almasına sebep olarak düşündüğü nedeni şu şekilde ifade etti: "Neden kilo aldım.... Ben bir ameliyat geçirdim. Oradan aldığım ilaçlarla. Kortizonlu ilaçlarım vardı. Onlardan dolayı hızlı kilo aldım. Veremedim." (Katılımc 11, BKi: 52,54) Depresyon, anksiyete ve tip II diyabet gibi hastalıkların tedavisinde kullanılan ilaçların da obeziteye neden olabileceği düşünülmektedir (9). Bu nedenle, özellikle kronik hastalıkları olan ve bazal metabolizma üzerinde yavaşlatıcı etkisi olduğu düşünülen ilaçları kullanmak zorunda olan kişilerin, kişiye uygun bir diyet ve egzersiz programı ile birlikte bu süreci geçirmesi desteklenmelidir. Düzenli bir egzersiz ve beslenme tedavisi ile obezitenin gelişmesi engelleneceği gibi obezite nedeni ile gelişebilecek hastalıkların da önüne geçilebilecektir.

\section{Obeziteden kurtulmuş bireylerin obeziteye yönelik düşünceleri}

Obeziteden kurtulmaya karar vermede etkili olan nedenler Obeziteden kurtulmuş olan katılımcılara, obeziteden kurtulmak için karar vermede hangi faktörlerin ya da yaşadıkları hangi olayların etkili olduğunu sorduğumuzda katılımcıların tamamının $(n=15)$ psikososyal etkilerden söz ettikleri tespit edildi (Tablo 3 ).

\section{Psikososyal etkiler}

Katılımcılardan bazıları obeziteden kurtulmaya karar vermelerinde etkili olan nedenleri şu şekilde ifade etmişlerdir. 'Obeziteye kurtulmayaaa (düşünerek cevap veriyor) bundan yaklaşık 3 yıl önce falan lise dönemindeyken karar verdim. Zaten hayatımda verdiğim en büyük karardı. O insanlardaki bakışı gördükten sonra verdim. Insanların ben hareket ederken vücuduma bakışı, adımlarımı izleyişi benim dikkatimi çekiyordu. Yani insanlar farklı bakıyor.. Kilolu olmak kötü bir durum. Farklı reaksiyonlar ve tepkiler alıyordum yani." (Katılımcı A2, 21 yaşında). "Obeziteden kurtulmaya yaklaşık bir yıl önce bir ortamda arkadaşlarla beraber bir resim çektirmiştim. Resimde daha fazla kilo aldığımı fark ettim. Ellerim vesaire şişmişti. Yüzüm falan... Gayet kilolu duruyordum. O zamana kadar işin o kadar farkında değildim. Ogün karar verdim. Diyete başladım." (Katılımcı A1, 25 yaşında). "Dışarıda arkadaşlarımla mesela.. Giydiğim kıyafetler falan beni çok rahatsız etti. Öyle karar verdim kilo vermeye. Yani ergenlik dönemimde kilo vermeye başladım. Arkadaş ortamım beni çok etkiledi." (Katılımcı A4, 21 yaşında). Obezitenin psikolojik sonuçlarının benlik saygısında düşüklükten depresyona kadar geniş bir etki alanının olduğu söylenebilmektedir. Özellikle genç bireylerin kendi bedensel yapıları ve değişimleri ile daha fazla ilgilendiği ergenlik döneminde, obezitenin neden olabileceği fiziksel değişimler daha fazla psikolojik sonuçların ortaya çıkmasına neden olmaktadır. Toplumun şişman kişilere karşı gösterdiği tepki ve damgalama nedeni ile bu bireylerde daha fazla anksiyete ve suçluluk duygusunun ortaya çıkabileceği düşünülmektedir. Bir grup obez birey ve kontrol grubu olarak seçilen normal kiloda olan bireyler ile yapılan bir çalışmada (2015) obez bireylerin anksiyete ve depresyon düzeyinin normal kiloda olan bireylere oranla daha yüksek olduğu tespit edilmiştir (18). Aynı düşünce ile yapılan başka bir çalışmada (2014) ise, obez bireylerin obez olmayan bireylere oranla benlik saygılarının daha düşük olduğu ve bedenlerinden hoşnut olmadıkları tespit edilmiştir (14).

Obez bireylerin benlik saygılarının obez olmayan bireylerden daha düşük olduğu göz önüne alındığında benlik saygısı düşük olan bireylerin sosyal ortamlarda anksiyete düzeylerinin de diğer kişilere oranla daha yüksek olacağını söylemek yanlış olmayacaktır. Ayrıca arkadaş çevrelerince reddedilme ve beğenilmeme kaygıları ile daha fazla psikolojik bozukluk ve somatik yakınmalar gelişebilmektedir. Mevcut çalışmada da görüleceği gibi, kişilerin obeziteden fiziksel anlamda zarar görmelerine rağmen, obeziteden 
kurtulmaya karar vermelerinde psikososyal faktörlerin daha etkili olduğunu söylemek mümkündür. Bu nedenle obez bireylerin, özellikle anksiyete ve beden algısı gibi konularda daha titiz bir şekilde değerlendirilmesi ve desteklenmesi gerekmektedir.

\section{Obeziteden kurtulduktan sonra oluşan değişimler}

Katılımcılara obeziteden kurtulduktan sonra hayatlarında meydana gelen değişiklikler soruduğunda bazı katılımcıların özgüvenlerinin arttığını ifade etikleri, bazı katılımcıların ise fizyolojik anlamda yaşam kalitelerinin arttığını ifade ettikleri görülmüştür.

\section{Özgüvenin artması}

Katılımcılardan bazıları obeziteden kurtulduktan sonra özgüvenlerinin arttığını ve sosyal olarak kendilerini daha rahat hissettiklerini şu sözlerle ifade etmişlerdir: "Süreçten sonra şöyle söyleyebilirim düşünce yapım değişti. Yani daha çok sosyal ortamlara girebiliyorum. Kendi özgüvenim gelişti. Giydiğim kıyafetler mesela eskiden giyerken hiç beğenmezken şimdi giydiğim kıyafetlerin üzerimde güzel durması... Güzel bir his yani." (Katılımcı A14, 21 yaşında), " Özgüvenim... Tamamen yerine geldi. Bunu hissediyorum (gururlanarak gülümsüyor). Çevremdeki insanların geçmişte ve şu andaki bakış açılarının değiştiğini görmek... Beni de aralarına almaları... Artık mağazalarda rahatça dolaşabiliyorum, elbise deneyebiliyorum. Giydiklerimin yakıştığını görebiliyorum. Bu sebepler yeterli benim için (Katılımcı A5, 22 yaşında). Çocukluk çağı ve ergenlik döneminde obezite varlığının bireylerde özgüven eksikliğine sebep olduğu, Herman (1979) ve Strauss'un (2000) yaptığı çalışmalarda ortaya koyulmuştur $(15,19)$. Ülkemizde yapılan bir başka çalışmada ise, obez adölesanlardaki psikolojik problemlerin ve özgüven eksikliğinin daha yüksek olduğu tespit edilmiştir (20). Özellikle okul çağındaki obez çocuklarda ve gençlerde, ortamda kendini kabul ettirememe ya da alay konusu olma gibi korkular nedeni ile derslere devamsızlık ve başarı durumunun gerilemesi gibi problemlerle karşılaşmak mümkündür. Mevcut çalışmadan örnek verilen ifadelerden de yola çıkarak, obezitenin özellikle genç popülasyonu psikolojik bağlamda daha çok etkilediğini söylemek mümkündür. Obeziteden kurtulmuş bireyler sosyalleşmek ya da kendilerini kanıtlamak için öncelikle özgüvenlerinin tam olması gerekliliği üzerinde durmuş ve obeziteden kurtulduklarında kendilerini daha iyi hissettiklerini ifade etmişlerdir.

\section{Fizyolojik yaşam kalitesinin artması}

Bazı katılımcılar obeziteden kurtulduktan sonra fizyolojik yaşam kalitelerinin arttığını; " Kilo verdikten sonra daha rahat hareket ediliyor. En basitinden insan oturup kalkarken daha rahat oluyor. Terleme neredeyse hiç olmuyor. Daha uzun yürüyüşler yapılıyor, daha az yoruluyorsun. Merdiven çıkarken daha az nefes nefese kalıyorsun." (Katılımcı A11, 33 yaşında) ve "Şu anda vücudumu çok güzel bir düzene soktum. Hayatım gerçekten güzel bir düzene girdi spor sayesinde beslenmelerim sayesinde. Kendimi çok iyi hissediyorum. Aktivitelerde daha başarılıyım. Daha fazla efor sarf edebiliyorum." (Katılımcı A12, 31 yaşında) sözleri ile ifade ettiler. Aktivite yetersizliği obeziteye sebep olabileceği gibi obezite de aktivite yetersizliğine sebep olmaktadır. Bu kişiler aşırı vücut ağırlığının sebep olduğu diz, kalça, bel, sırt ağrıları nedeniyle fiziksel aktivitede kısıtlama yapmak zorunda kalmakta ve hareketsiz bir yaşam ile birçok metabolik hastalığa da zemin hazırlamaktadırlar. Obez bireylerdeki fazla kilo artışıyla birlikte ortaya çıkan özellikle kas- iskelet sistemi hastalıklarına ek olarak deri hastalıklarının da oldukça sık karşılaşılan bir tablo olduğu söylenebilir. Obezite, deri fizyolojisini, subkutan yağ doku yapısını ve ter bezi fonksiyonlarını da doğrudan etkilemektedir (21). Chakravarti ve ark.'nın (2002) yaptığı bir çalışmada obez kişilerin transepidermal sıvı kaybının kontrol grubuna oranla daha yüksek olduğu saptanmıştır (22). Özellikle vücudun kıvrımlı bölgelerinde oluşabilecek deri irritasyonunun sebep olacağı kaşıntı, yanma ve yangı nedeniyle de obez bireylerin fiziksel aktivitelerinin azalma eğilimi göstereceği düşünülmektedir (21). Gerek cilt problemlerinin sosyal ortamlarda verdiği rahatsızlık nedeniyle, gerekse eklem ağrılarının sebep olduğu fiziksel zorlanmalar ve efor nedeniyle obez bireyler konforlu bir yaşam sürememektedir. Mevcut çalışmada da görüleceği üzere, kilo kaybı ile birlikte kişiler yaşam kalitelerinin de arttığını ifade etmişlerdir.

\section{Sonuç}

Obezite, kişilerin hayatını yalnızca fiziksel olarak değil, psikolojik anlamda da olumsuz yönde etkileyen günümüzün en önemli ve hızla artan kronik halk sağlığı problemlerinden birisidir. Gelişen teknoloji ve küreselleşmenin de etkisiyle hareketsiz yaşam tarzının kaçınılmaz hale geldiği son yıllarda, obezitenin ergenlik dönemine hatta çocukluk dönemine kadar indiği görülmektedir. Obezitenin, özellikle okul çağı dönemindeki genç nüfusta yarattığı özgüven eksikliğinin asosyal yaşam biçimine sebep olduğu bilinen bir gerçektir. Sosyal çevreden uzak kalmak obez bireylerde majör depresyon, uyum bozukluğu ve anksiyete bozukluğu gibi birçok psikiyatrik hastalıkları da beraberinde getirecektir. Obez çocukların ailelerinin yaşam kalitesi algılarının ve bu ailelerde obeziteye rastlanma oranının da daha yüksek olduğu bilinmektedir (23). Bu da obezitenin 
bireysel bir sorundan ziyade ailesel bir problem olduğunu göstermektedir. Bu nedenle obez bireylerin yalnızca mevcut ya da potansiyel fizyolojik sağlık problemleri açısından değil, psikolojik anlamda da değerlendirilmesi; tedavi sürecinin yalnızca bireysel olarak değil, ailenin de dâhil edileceği multidisipliner bir yaklaşımla yürütülmesi gerekmektedir.

\section{Kaynaklar}

1. WHO. Obesity and overweight. https://www.who.int/en/ news-room/fact-sheets/detail/obesity-and-overweight

2. Altunkaynak BZ, Özbek E. Obezite: nedenleri ve tedavi seçenekleri. Van Tıp Derg 2006;13:138-42. https://www.journalagent.com/vtd/ pdfs/VTD_13_4_138_142.pdf

3. Esen Ö. Obezite Tanısı Almış Bireylerde Stresle Başa Çıkma Tarzları ve Benlik Saygısı Arasındaki İlişkinin İncelenmesi. Yayımlanmamış yüksek lisans tezi. Haliç Üniversitesi, Sosyal Bilimler Enstitüsü, İstanbul. 2017.

4. Levin B. Synergy of nature and nurture in the development of childhood obesity. Int J Obes 2009;33:S53-6. [CrossRef] https://doi. org/10.1038/ijo.2009.18

5. Özbahar Acar Z. Üniversite Öğrencilerinde Obezite ve Yaşam Davranışları. Uzmanlık tezi. Ondokuz Mayıs Üniversitesi, Samsun, 2015.

6. Güven S, Özdemir O, Dinçer F. Osteoartrit ve Obezite İlişkisi. J Phys Med Rehabil Sci 2016;19:76-84. http://www.jpmrs.org/uploads/ pdf_PMJ_570.pdf

7. Eren İ, Erdi Ö. Obez hastalarda psikiyatrik bozuklukların sıklığı. Klin Psikiyatr 2003;6:152-7. https://www.journalagent.com/kpd/pdfs/ KPD_6_3_152_157.pdf

8. Koçak Y. Çocukluk Çağındaki İlkokul Öğrencilerinde Obezite Yaygınlığı, Beslenme Alışkanlıklarının Obeziteye Etkileri. Yalova Üniversitesi; 2014.

9. Kayar H, Utku S. Çağımızın Hastalığı Obezite ve Tedavisi. Mersin Üniv Sağlık Bilim Derg 2013;6. https://dergipark.org.tr/tr/download/ article-file/182768

10. TÜiK. TÜIK [Internet] 2017. http://www.tuik.gov.tr/Start.do

11. Hammond RA, Levine R. The economic impact of obesity in the United States. Diabetes, Metab Syndr Obes 2010;3:285-95. [CrossRef]

12. Erdoğan S, Nahcivan N, Esin N. Hemşirelikte Araştırma: Süreç, uygulama ve kritik. İstanbul: Nobel Tıp Kitabevleri; 2014. pp.131-64.
Türkiye'de obezite insidansının düşürülmesi, gelecek kuşakların daha sağlıklı bir yaşam sürebilmesi ve aynı zamanda ülke ekonomisindeki yükünün de hafifletilmesi için halkın hareketli yaşam ve sağlıklı beslenme hakkında bilinçlendirilmesi gerekmektedir. Halk sağlığı çalışanları obezitenin psikolojik yönlerini saptamaya çalışmalı ve elde edilen sonuçlar doğrultusunda koruyucu önlemler alınmalıdır.

13. Giannini E, Ruperto N, Ravelli A, Lovell D, Felson D, Martini A. Preliminary definition of improvement in juvenile arthritis. Arthritis \& Rheumatism. Off J Am Coll Rheumatol 1997;40:1202-9. [CrossRef]

14. Tezcan B. Obez Bireylerde Benlik Saygısı, Beden Algısı ve Travmatik Geçmiş Yaşantılar. Uzmanlık tezi. İstanbul, 2009. http://www. istanbulsaglik.gov.tr/w/tez/pdf/psikiyatri/dr_bahar_tezcan.pdf

15. Strauss RS. Childhood obesity and self-esteem. Pediatrics 2000;105:e15. [CrossRef]

16. Chan KKW, Sit RWS, Wu RWK, Ngai A. Clinical, Radiological and Ultrasonographic Findings Related to Knee Pain in Osteoarthritis. PLoS One 2014;9:e92901. [CrossRef]

17. Ata A, Vural A, Keskin F. Beden Algısı ve Obezite. Ankara Med J 2014;14. [CrossRef]

18. Değirmenci T, Kalkan-Oğuzhanoğlu N, Sözeri-Varma G, Özdel O, Fenkçi S. Obezitede Psikolojik Belirtiler ve İlişkili Etmenler. Arch Neuropsychiatr 2015;52:42-6. [CrossRef]

19. Herman A, Yu K. Adolescent age at first pregnancy and subsequent obesity. Paediatr Perinat Epidemiol 1997;11:130-41. [CrossRef]

20. Erermis S, Cetin N, Tamar M, Bukusoglu N, Akdeniz F, Goksen D. Is obesity a risk factor for psychopathology among adolescents? Pediatr Int 2004;46:296-301. [CrossRef]

21. Açıkgöz G, Meral A, Çayırlı M. Obezite ve Deri Hastalıkları. Anatol J Clin Investig 2013;7:180-5. https://docplayer.biz.tr/18076980Obezite-ve-deri-hastaliklari.html

22. Chakravarti A, Loeffler J, Dyson N. Insulin-like growth factor receptor I mediates resistance to anti-epidermal growth factor receptor therapy in primary human glioblastoma cells through continued activation of phosphoinositide 3-kinase signaling. Cancer Res 2002;62:200-7. https://cancerres.aacrjournals.org/content/ canres/62/1/200.full.pdf

23. Önder A, Kavurma C, Çelmeli G, Adanır A, Özatalay E. Obezite tanılı çocuk ve ergenlerde psikopatoloji, yaşam kalitesi ve ebeveyn tutumlarının değerlendirilmesi. İzmir Dr Behçet Uz Çocuk Hast Derg 2018;8:51-8. [CrossRef] 